\title{
Screening for Chlamydia Trachomatis Infection among Pregnant Women in a Tertiary Care Hospital
}

\author{
C. Anitha*, S. Senthamarai and S. Sivasankari \\ Department of Microbiology, Meenakshi Medical College Hospital and Research Institute, \\ Enathur, Kanchipuram-631552, India \\ *Corresponding author
}

\begin{abstract}
A B S T R A C T
To determine the prevalence of Chlamydia trachomatis urogenital infection and to identify behavioral, demographic, and clinical factors associated with the infection in pregnant women's. One-hundred-eleven patients 15-39 years old, at 10-16 weeks of gestation and attending the prenatal clinic at our hospital, were tested for Chlamydia trachomatis infection by using ELISA IgM to screen all the young women with PID, Infertility for Chlamydial infections.50 negative groups were included in the study. In this cohort, out of 111 patients $76(68.5 \%)$ pregnant women were found positive for IgM antibodies. The cut off value for ELISA test is 0.558.Pregnant women's within the age of 20-35 were taken positive if the value is 0.558 and 0.999 with less than $>1.000$ were low positive. So out of 76 positive patients $48(43.24 \%)$ were low positive by ELISA IgM and 28 $(25.22 \%)$ were in the high positive category in the age group 25-32 years. Statistical significance was observed when high positive and negative groups were compared. High positivity was observed mostly in the first trimester of the pregnancy. None of the factors associated with chlamydial infection was sensitive enough to permit efficient selective screening. It is cost effective to recommend a routine screening for chlamydial infection together with an educational program. We stress the importance of large-scale screening of pregnant women for C. trachomatis infection, particularly in developing countries where sophisticated techniques for collection/diagnosis are as yet unavailable.
\end{abstract}

\section{Introduction}

Chlamydia trachomatis is one of the most common sexually transmitted treatable infection worldwide. C.trachomatis are silent clinical infections having a major public health concern (1). In womens C.trachomatis infection can lead to tubal infertility, Pelvic inflammatory disease, ectopic pregnancy etc (2-5). During pregnancy chlamydia infection influences the pregnancy outcomes such as premature membrane rupture, low birth weight, mortality and other infections involving conjunctiva and respiratory infections (6-8).

Untreated co morbid sexually transmitted infection (STI) predisposes the risk of acquiring HIV with early detection and treatment of STI's burden of HIV can be reduced (9-25). Screening of C.trachomatis in pregnant women can reveal the prevalence rate of C.trachomatis. In general the prevalence rate ranges from $0-37 \%$ with 
underlying associated comorbid risk factors including socioeconomic status and age of the patients $(23,25)$. Diagnosis of STI's in developing countries is essential based on symptoms, physical examination, clinical criteria than laboratory diagnosis. Hence we undertook the study to assess the prevalence of C.trachomatis infection in pregnant women.

\section{Materials and Methods}

\section{Study design}

\section{Demographic details}

The patient's details were obtained from hospital record and the information recorded include age, sex, clinical diagnosis, duration of hospital stay, antibiotic usage.

\section{Sample size}

111 from study population,50 samples from healthy women's were collected served as a control group.

\section{Samples collected}

Blood collected and Serum separated

\section{Hospital}

Meenakshi Medical College \& Research Institute, Kanchipuram.

\section{Period of study}

March 2019- July 2019

\section{Age group}

\section{5-39 years old}

\section{Inclusion criteria}

Pregnant women's at 10-16 weeks of gestation are included.

Prior to antibiotics administration samples were collected.

\section{Exclusion criteria}

Prior diagnosed STI patients were excluded

\section{Methods}

A total of 111 blood samples were collected from study group population after getting their informed consent.50 samples from healthy women's were collected served as a control group. The study was carried out in Department of Microbiology, Meenakshi Medical College Hospital and Research Institute, Kanchipuram.

The study was approved by Institutional ethical board. All the blood samples were collected and transported to Microbiology laboratory. The serum was separated and stored until use.

\section{IgM ELISA}

Detection of $\operatorname{IgM}$ antibodies against C.trachomatis was done from serum samples collected. The IgM was detected using the ELISA kit (Novum diagnostics) following the manufacturer's instruction. The sample were considered positive for IgM if the absorbance value is more than $10 \%$ of the cutoff value as per manufacturer's protocol.

\section{Results and Discussion}

Out of 111 patients $76(68.5 \%)$ pregnant women were found positive for IgM antibodies. The cut off value for ELISA test is 0.558.Pregnant women's within the age of 2035 were taken positive if the value is 0.558 and 0.999 with less than $>1.000$ were low positive. Out of 76 positive patients 48 
(43.24\%) were low positive by ELISA IgM. $28(25.22 \%)$ were in the high positive category in the age group 25-32 years. (Table 1, Graph 1). In our study all the positive patients both high and low positivity were in the age group of 25-32 years of age (Table 2, Graph.2).

In our study 111 pregnant women's included of which $76(68.5 \%)$ were positive which includes high and low positivity whereas in control group population only $4(8 \%)$ were positive for presence of IgM against C.trachomatis (Graph 3).

Statistical significance were observed when high positive and negative groups were compared $(\mathrm{p}<0.05)$. High positivity was observed mostly in the first trimester of the pregnancy. No statistical significance was observed in the control group.

In the present study prevalence of C.trachomatis is $25.22 \%$ observed which is less compared to global reports with $29.4 \%$, $38.3 \%$, 56.1\% respectively (26-29). The present study differs from others in age group, geographic distribution and socioeconomic status of the individual with similar method of diagnosis (30). In the present study when age group is compared to rate of prevalence of infection we found 25-32 years are more prone which is almost concordant with other studies which reports 25-29 years having higher rate of C.trachomatis infection (30). When high positive rate of C.trachomatis infection was compared in our study we observed females in $1^{\text {st }}$ trimester are more prone for high positive trachomatis infection which is similar to other studies (31).

Early detection and prompt treatment of STI's are the only strategy to prevent the infection (32). Regular screening of asymptomatic STI's will have major impact on public health and will have financial burden on patients quality care. In accordance with other studies we observed that improved routine cost effective periodic screening to detect C.trachomatis infection would reduce the disease burden considerably (33-39).further studies with large sample size and molecular methods detection of C.trachomatis will give a clear insight about the magnitude of C.trachomatis infection.

Table.1 Number positivity in study and control group population

\begin{tabular}{|l|c|c|}
\hline Total Number of samples & High Positivity (\%) & Low Positivity (\%) \\
\hline Study population (N=111) & $28(25.22 \%)$ & $48(43.24 \%)$ \\
\hline Control population (N=50) & $4(8 \%)$ & - \\
\hline
\end{tabular}

Table.2 Age wise distribution among study and control group

\begin{tabular}{|l|c|c|c|c|}
\hline \multirow{2}{*}{ Age (years) } & \multicolumn{2}{|c|}{ Study group (n=111) } & \multicolumn{2}{c|}{ Control group (N=50) } \\
\cline { 2 - 5 } & High Positivity & Low positivity & High Positivity & Low Positivity \\
\hline $\mathbf{1 5 - 2 5}$ & 0 & 0 & 0 & 0 \\
\hline $\mathbf{2 5 - 3 5}$ & $28(25.22 \%)$ & $48(43.24 \%)$ & $4(8 \%)$ & 0 \\
\hline $\mathbf{3 5 - 4 5}$ & 0 & 0 & 0 & 0 \\
\hline
\end{tabular}


Graph.1 Number positivity in study and control group population

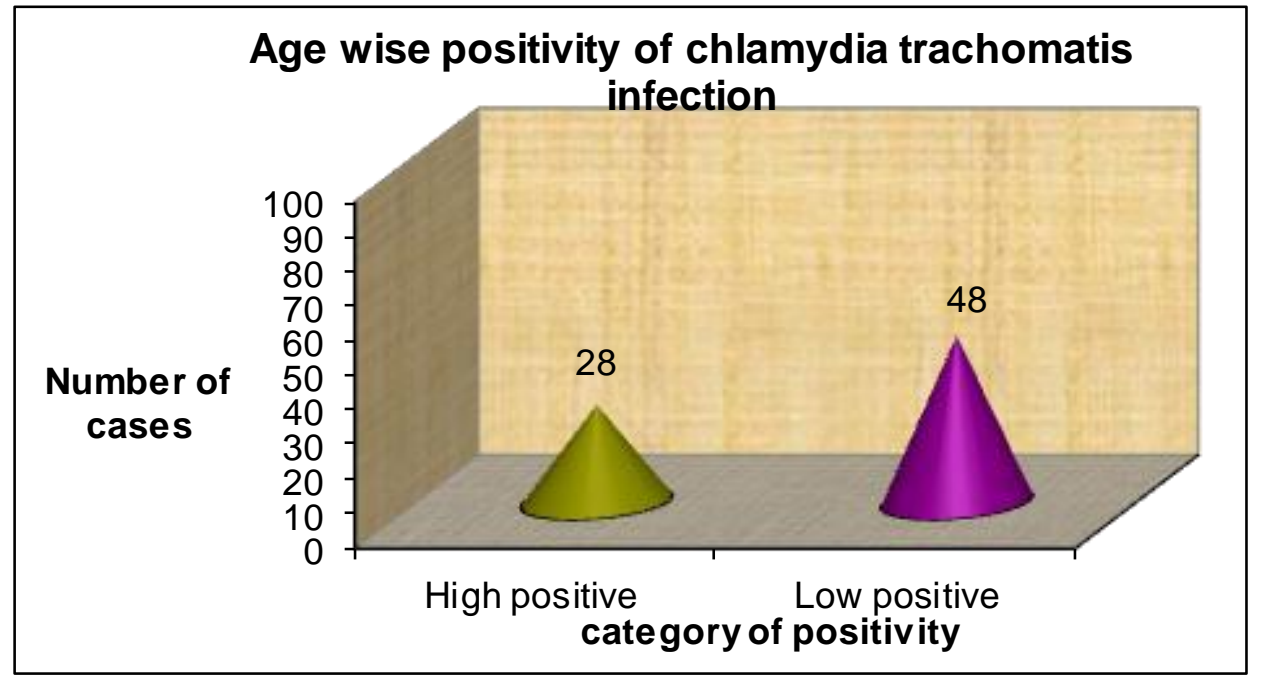

Graph.2 Age wise distribution among study and control group

Comparison of positivity among pregnant and

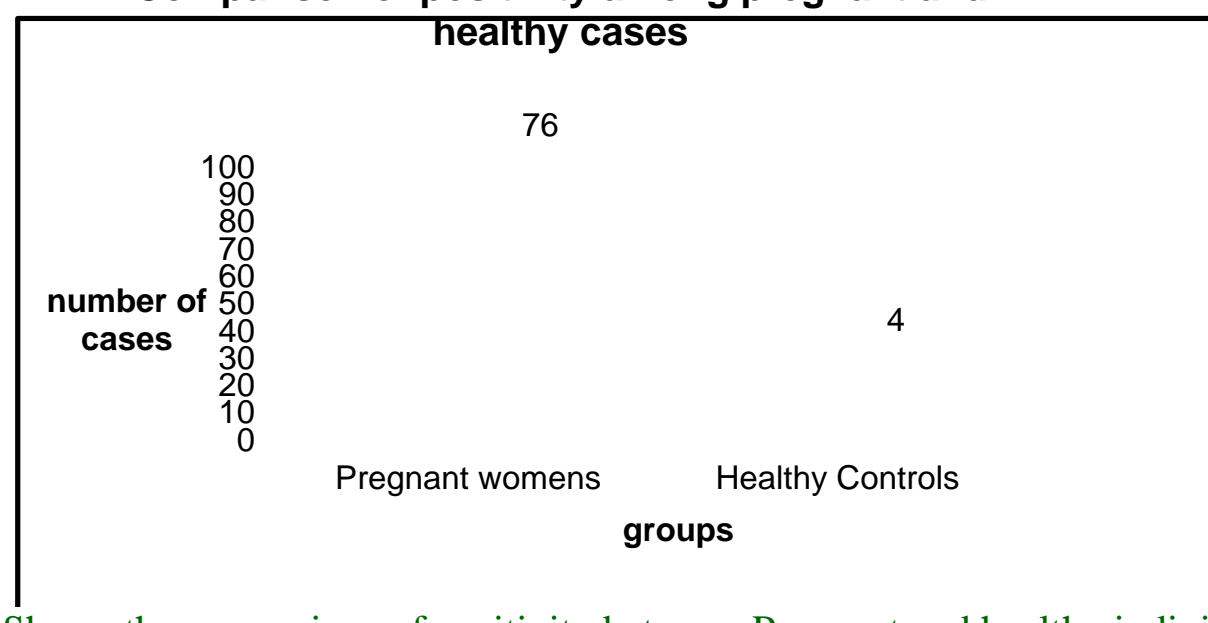

Graph.3 Shows the comparison of positivity between Pregnant and healthy individuals 
Since it is cost effective we emphasis a routine screening for chlamydial infection together with an educational program. From our study we stress the importance of largescale screening of pregnant women for $C$. trachomatis infection and access to treatment among the high risk patients which would substantially reduce the risk of HIV transmission and disease progression

\section{Acknowledgement}

I thank MAHER University for providing me the SEED MONEY FUND to Conduct and Complete this study in a successful manner. I also thank our Dean Meenakshi medical college hospital and Research institute for her constant encouragement and support.

\section{References}

Alger LS, Lovchik JC, Hebel JR, Blackmon LR, Crenshaw MC. The association of Chlamydia trachomatis, Neisseria gonorrhoeae, and group B streptococci with preterm rupture of the membranes and pregnancy outcome. Am J Obstet Gynecol. 1988;159(2):397-404.

Andrews WW, Goldenberg RL, Mercer B, Iams J, Meis P, Moawad A, et al., The preterm prediction study: association of second-trimester genitourinary chlamydia infection with subsequent spontaneous preterm birth. Am J Obstet Gynecol. 2000; 183(3):662-8.

Association of Chlamydia trachomatis and Mycoplasma hominis with intrauterine growth retardation and preterm delivery. The John Hopkins Study of Cervicitis and Adverse Pregnancy Outcome. Am J Epidemiol. 1989;129(6):1247-57.

Atkins MC, Carlin EM, Emery VC, Griffiths PD, Boag F. Fluctuations of HIV load in semen of HIV positive patients with newly acquired sexually transmitted diseases. BMJ 1996; 313: 341-42.

Blas MM, Canchihuaman FA, Alva IE, Hawes SE. Pregnancy outcomes in women infected with Chlamydia trachomatis: a population-based cohort study in Washington State. Sex Transm Infect. 2007;83(4):314-8.

Centers for Disease Control and Prevention. Sexually Transmitted Disease Surveillance 2008. Atlanta, GA: US Department of Health and Human Services; 2009.

Claman P, Toye B, Peeling RW, Jessamine P, Belcher J. Serologic evidence of Chlamydia trachomatis infection and risk of preterm birth. CMAJ. 1995;153(3):259-62. 17. Nadisauskiene R, Bergstrom S, Stankeviciene I, Spukaite T. Endocervical pathogens in women with preterm and term labour. GynecolObstet Invest. 1995;40(3):17982.

Darville T. Chlamydia trachomatis infections in neonates and young children. Semin Pediatr Infect Dis. 2005;16(4):235-44.

Gencay M, Koskiniemi M, Ammala P, Fellman V, Narvanen A, Wahlstrom T, et al., Chlamydia trachomatis seropositivity is associated both with stillbirth and preterm delivery. APMIS. 2000;108(9):584-8.

Ghys PD, Fransen K, Diallo MO, Virginie ET, Issa-Malick C, Kouadio M.Y, et al., The associations between Cervicovaginal HIV shedding, sexually transmitted diseases and immunosuppression in female sex workers in Abidjan, Céte d'Ivoire. AIDS 1997; 11: F85-F93.

Gilson L, Mkanje R, Grosskurth H, Mosha F, Picar J, Gavyole A, et al., Costeffectiveness of improved treatment services for sexually transmitted diseases in preventing HIV-1 infection in Mwanza Region, Tanzania. Lancet 1997; 350: 1805-09. 
Gravett MG, Nelson HP, DeRouen T, Critchlow C, Eschenbach DA, Holmes KK. Independent associations of bacterial vaginosis and Chlamydia trachomatis infection with adverse pregnancy outcome. JAMA. 1986; 256 (14):1899-903.

Harrison HR, Alexander ER, Weinstein L, Lewis M, Nash M, Sim DA. Cervical Chlamydia trachomatis and mycoplasmal infections in pregnancy. Epidemiology and outcomes. JAMA. 1983;250(13):1721-7.

HIV prevention through early detection and treatment of other sexually transmitted diseases-United

States.

Recommendations of the Advisory Committee for HIV and STD Prevention. MMWR Recomm Rep 1998; 47(RR-12); 1-24.

Ikeme AC, Ezegwui HU, Ikeako LC, Agbata I, Agbata E. Seroprevalence of Chlamydia trachomatis in Enugu, Nigeria. Niger J ClinPract 2011; 14:176-80. 24.

Jeremiah I, Okike O, Akani C. The prevalence of serum immunoglobulin $\mathrm{G}$ antibody to Chlamydia trachomatis in subfertile women presenting at the university of Port Harcourt teaching hospital, Nigeria. Int $\mathrm{J}$ Biomed Sci 2011;7:120-4.

Joyee AG, Thyagarajan SP, Reddy EV, Venkatesan C, Ganapathy M. Genital Chlamydial infection in STD patients: Its relation to HIV infection. Indian $\mathbf{J}$ Med Microbiol. 2005; 23: 37-40.

Kesavaram Padmavathy, Susethira Aruppukottai R., Padma Krishnan, Rajasekaran Shikamani, Kailapuri A. Murugavel., Uma Shanmugasundaram. IgM ELISA: A Better Choice for the Detection of Active Chlamydia trachomatis Infection among HIV Patients. Journal of Clinical and Diagnostic Research. 2012 February,
Vol-6(1): 34-37

Kovacs L, Nagy E, Berbik I, Meszaros G, Deak J, Nyari T. The frequency and the role of Chlamydia trachomatis infection in premature labor. Int $\mathbf{J}$ Gynaecol Obstet. 1998;62(1):47-54.

Manavi K. A review on infection with Chlamydia trachomatis. Best Pract Res ClinObstetGynaecol. 2006;20(6):94151.

Mardh PA. Influence of infection with Chlamydia trachomatis on pregnancy outcome, infant health and life-long sequelae in infected offspring. Best Pract Res ClinObstetGynaecol. 2002; 16(6):847-64.

Martin DH, Eschenbach DA, Cotch MF, Nugent RP, Rao AV, Klebanoff MA, et al., Double-blind placebo-controlled treatment trial of Chlamydia trachomatis endocervical infections in pregnant women. Infect Dis Obstet Gynecol. 1997;5(1):10-7.

Martin DH, Koutsky L, Eschenbach DA, Daling JR, Alexander ER, Benedetti JK, et al., Prematurity and perinatal mortality in pregnancies complicated by maternal Chlamydia trachomatis infections. JAMA. 1982;247(11):15858.

Mawak JD, Dashe W, Agabi YA, Panshak BW. Prevalence of genital chlamydia among gynaecologic clinic attendees in Jos, Nigeria. Shiraz E Med J 2011;12:100-3

Ngassa PC, Egbe JA. Maternal genital Chlamydia trachomatis infection and the risk of preterm labor. Int J Gynaecol Obstet. 1994;47(3):241-6.

Odendaal HJ, Schoeman J. The association between Chlamydia trachomatis genital infection and spontaneous preterm labour. S. Afr J ObstetGynaecol. 2006;12(3):146-9. 24. Andrews WW, Klebanoff MA, Thom EA, Hauth JC, Carey JC, Meis PJ, et al., Midpregnancy 
genitourinary tract infection with Chlamydia trachomatis: association with subsequent preterm delivery in women with bacterial vaginosis and Trichomonas vaginalis. Am J Obstet Gynecol. 2006;194(2):493-500.

Peipert JF. Clinical practice. Genital chlamydial infections. N Engl J Med. 2003;349(25):2424-30.

Rastogi S, Kapur S, Salhan S, Mittal A. Chlamydia trachomatis infection in pregnancy: risk factor for an adverse outcome. $\mathrm{Br}$ J Biomed Sci. 1999;56(2):94-8.

Rours GIJG, Hammerschlag MR, Ott A, De Faber TJ, Verbrugh HA, de Groot R, et $a l$. . Chlamydia trachomatis as a cause of neonatal conjunctivitis in Dutch infants. Pediatrics. 2008; 121(2):e321-6.

Rours GIJG, Hammerschlag MR, Van Doornum GJ, Hop WC, de Groot R, Willemse HF, et al., Chlamydia trachomatis respiratory infection in Dutch infants. Arch Dis Child. 2009; 94(9):705-7.

S. Bello, K. Tunau, S. Nasir, M. Yahaya1, A. Panti, M. Hassan, E. I. Nwobodo, B. A. Ekele2.Prevalence of genital Chlamydia trachomatis infection among patients attending a gynecological clinic in a tertiary hospital.Sahel Medical Journal /
Volume 22 Issue 4 / OctoberDecember 2019pg 188-193.

Sexually transmitted diseases treatment guidelines 2002. Centers for Disease Control and Prevention. MMWR Recomm Rep. 2002; 51(RR-6):1-78.

Sweet RL, Landers DV, Walker C, Schachter J. Chlamydia trachomatis infection and pregnancy outcome. Am J Obstet Gynecol. 1987;156(4):824-33.

Tukur J, Shittu SO, Abdul AM. A case control study of active genital Chlamydia trachomatis infection among patients with tubal infertility in Northern Nigeria. Trop Doct 2006;36:14-6.

Wasserheit JN. Epidemiological synergy. Interrelationships between human immunodeficiency virus infection and other sexually transmitted diseases. Sex Transm Dis 1992; 19: 61-77.

Wiesenfeld HC, Hillier SL, Krohn MA, Amortegui AJ, Heine RP, Landers DV, et al., Lower genital tract infection and endometritis: insight into subclinical pelvic inflammatory disease. Obstet Gynecol. 2002;100(3):456-63.

World Health Organization. Global prevalence and incidence of selected curable sexually transmitted infections: Overview and estimates.

\section{How to cite this article:}

Anitha, C., S. Senthamarai and Sivasankari, S. 2020. Screening for Chlamydia trachomatis Infection among Pregnant Women in a Tertiary Care Hospital. Int.J.Curr.Microbiol.App.Sci. 9(07): 894-900. doi: https://doi.org/10.20546/ijcmas.2020.907.104 